\title{
High throughput measurements of BMP/BMP receptors interactions using bio-layer interferometry
}

Valia Khodr ${ }^{1,2}$, Paul Machillott ${ }^{1,2}$, Elisa Migliorini ${ }^{1,2}$, Jean-Baptiste Reiser ${ }^{3}$, Catherine Picart ${ }^{1,2^{*}}$

${ }^{1}$ Interdisciplinary Research Institute of Grenoble (IRIG), ERL BRM 5000

(CNRS/UGA/CEA), CEA Grenoble, 17 rue des Martyrs, 38054 Grenoble cedex, France

${ }^{2}$ CNRS, Grenoble Institute of Technology, LMGP, UMR 5628, 3 Parvis Louis Néel, 38016

Grenoble

${ }^{3}$ Institut de Biologie Structurale, UMR 5075, Univ. Grenoble Alpes, CEA, CNRS, IBS, F-38000 Grenoble, France

*Corresponding author: Catherine Picart

E-mail: catherine.picart@cea.fr

Running title: Quantification of BMP/BMPR interactions

Keywords: Bone Morphogenetic Protein (BMP), receptor, protein-protein interaction, bio-layer interferometry (BLI), Surface Plasmon Resonance (SPR)

\begin{abstract}
Abbreviations
BMP-2, bone morphogenetic protein 2; BMP-4, bone morphogenetic protein 4; BMP-7, bone morphogenetic protein 7; BMP-9, bone morphogenetic protein 9; BMPR, Bone morphogenetic protein receptor; ALK1, Activin receptor-like kinase 1; ALK2, Activin receptor-like kinase 2; ALK3, Activin receptor-like kinase 3; ALK5, Activin receptor-like kinase 5; ALK6, Activin receptor-like kinase 6; ECD, extracellular domain; TGF $\beta$, transforming growth factor; TGF $\beta$, transforming growth factor receptor; BLI, Bio-layer interferometry; SPR, Surface plasmon resonance.
\end{abstract}

Conflict of interest: The authors declare that they have no conflicts of interest with the contents of this article. 


\begin{abstract}
Bone morphogenetic proteins (BMP) are an important family of growth factors playing a role in a large number of physiological and pathological processes, including bone homeostasis, tissue regeneration and cancers. In vivo, BMPs bind successively to both BMP receptors (BMPR) of type I and type II, and a promiscuity has been reported. In this study, we used bio-layer interferometry to perform parallel realtime biosensing and to deduce the kinetic parameters $\left(k_{a}, k_{d}\right)$ and the equilibrium constant $\left(K_{D}\right)$ for a large range of BMPs/BMPR combinations in similar experimental conditions. We selected four members of the BMP family (BMP-2, 4, 7, 9) known for their physiological relevance and studied their interactions with five type-I BMP receptors (ALK1, 2, 3, 5, 6) and three type-II BMP receptors (BMPRII, ACTR-IIA, ACTR-IIB). We reveal that BMP-2 and BMP-4 behave differently, especially regarding their kinetic interactions and affinities with the type-II BMPR. We found that BMP-7 has a higher affinity for ACTR-IIA and a tenfold lower affinity with the type-I receptors. While BMP-9 has a high and similar affinity for all type-II receptors, it can interact with ALK5 and ALK2, in addition to ALK1. Interestingly, we also found that all BMPs can interact with ALK5. The interaction between BMPs and both type-I and type II receptors immobilized on the same surface did not reveal further cooperativity. Our work provides a synthetic view of the interactions of these BMPs with their receptors and paves the way for future studies on their cell-type and receptor specific signaling pathways.
\end{abstract}

\title{
Introduction
}

Bone morphogenetic proteins (BMPs) are members of the transforming growth factor- $\beta$ (TGF $\beta$ ) superfamily who have been widely studied in view of the numerous physiological and pathological roles [1,2], including embryogenesis, development, bone homeostasis and regeneration and cancers [3]. The BMP family comprises more than 15 different ligands in humans, which have been grouped into four different subfamilies depending on their functions: BMP-2/4, BMP-5/6/7/8, BMP-9/10 and GDF5-6-7 [3-6].

Among these BMPs, BMP-2 is known for its role in morphogenesis, bone regeneration and musculoskeletal disorders [7,8]. In addition, BMP-4 plays a part in hematopoiesis and leukemia [9] while BMP-7 is involved in inflammation and glucose homeostasis [10]. BMP-9 and 10 have a major role in cardiovascular disease and anemia [11]. Furthermore, BMPs have been also reported to have an increasing role in cancer [12].

BMPs interact at the cell membrane with two sub-types of specific receptors (BMPR): type-I and type II BMPRs [2,4,5,13]. Seven different type-I receptors (ALK1 to ALK7) and four different type-II receptors (BMPR-II, ACTR-IIA, ACTR-IIB, TGF $\beta R$-II) are reported. BMPR-II, ACTR-IIA, ACTRIIB associated to binding of all BMPs, while TGF $\beta$ R-II are reported to be specific of TGF $\beta$ ligands, but not BMPs. BMPs have been reported to mostly bind to four receptors [3]: ALK1, ALK2 (also named ACTR-IA), ALK3 (also named BMPR-IA) and ALK6 (also named BMPR-IB). Each of these receptors has important physio-pathological roles. For instance, for the type-I BMPRs, ALK1 is the predominant receptor in endothelial cells and is involved in cardiovascular diseases [11]. ALK2 is an important receptor for bone homeostasis and a mutation in the ALK2 receptor is involved in a rare skeletal disorder named fibrodysplasia ossificans progressiva (FOP) and in a rare pediatric glioblastoma named diffuse intrinsic pontine glioblastoma (DIPG) [14], ALK3 plays a major role in several cancers, including breast and colorectal cancer [12], ALK6 plays a role in chronic myeloid leukemia [9,15]. ALK5 is reported to be a TGF $\beta$ receptor that is present in mesenchymal stem cells [16]. The three type-II receptors are usually considered to have similar roles in the signaling pathway associated to BMPs [3] but BMPR-II has likely been the most studied. Indeed, it was recently shown to play a protective role for endothelial cells from increased TGF $\beta$ responses and altered cell mechanics [17].

BMP signaling is initiated by the binding of BMPs to type-I BMPRs with high affinity prompting the constitutively active type-II BMPRs to come in close proximity to the formed complex, and induce the trans-phosphorylation of the glycine/serine-rich region (GS-box) preceding the kinase domain [1,18$20]$. In this signaling pathway, the high number of BMP ligands $(\approx 20)$ compared to the low number of BMP receptors (four type-I and three type-II receptors) indicates the presence of a promiscuous mechanism in which a given BMP can bind several receptors with distinct binding affinities [6][21]. 
bioRxiv preprint doi: https://doi.org/10.1101/2020.10.20.348060; this version posted October 21,2020 . The copyright holder for this preprint (which was not certified by peer review) is the author/funder, who has granted bioRxiv a license to display the preprint in perpetuity. It is made available under aCC-BY-NC-ND 4.0 International license.

Furthermore, it has been reported that high affinity ligands can compete with low affinity ligands for the binding of BMPRs and therefore can antagonize their signaling [22]. A better knowledge of the detailed binding characteristics of the BMPs to the BMPRs will help to identify the high affinity couples and to gain insight into the initiation of BMP signaling pathways.

To date, most of the characterizations of BMP/BMPR interactions have been determined using surface plasmon resonance (SPR) (23-37), which can be considered as a gold standard in the field. The data available from the literature of BMP/BMPR interactions are assembled in Table.1. However, the direct comparison of $\mathrm{K}_{\mathrm{D}}$ for the different BMPs and BMP receptors is difficult since data has been obtained using various experimental conditions (different protein constructs, different immobilization strategies, different buffers, different SPR instruments...), which introduces a large variability in the experimental data. In addition, this data focused on particular BMP/BMPR couples and there is a lack of data for BMP-4 and 9 as well as for ALK1.

Among all the biophysical methods available today to characterize protein-protein interactions, the reflectometric interference spectroscopy (RifS) $[38,39]$ is a very recent label-free optical method based on white light interferences at layers of sensors . A commercially-available setup known as bio-layer interferometry (BLI) enables to perform parallel real-time binding measurements and characterization of biomolecule interactions. It is increasingly used to study kinetic constants and binding affinities of protein-protein and protein-nucleic acid interactions [39-42] and it has only recently begun to be used to study BMP/activin A chimera interactions [30].

In the present study, our aim was to quantify in similar experimental conditions and a large set of BMP/BMPR interactions in a parallel manner, in order to directly compare their kinetic parameters and binding affinities. We decided to focus on four BMPs that are among the most widely studied: BMP-2, BMP-4, BMP-7 and BMP-9 [43]. For the type-I BMP receptors, we considered ALK1, ALK2, ALK3, ALK6 and added ALK5 known as an essential TGF $\beta$ receptor [44], since it is involved in the signaling of BMP-responsive cells such as mesenchymal stem cells [16]. We studied the three type-II BMP receptors (BMPR-II, ACTR-IIA and ACTR-IIB).

\section{Results}

We first performed a literature study to gain information on the state-of-the-art regarding BMP/BMPR interactions. Table.1 provides a view of the $\mathrm{K}_{\mathrm{D}}$ values, which are in the $\mathrm{nM}$ range for the highest affinity interactions. Table.SI.1 gives the detailed information obtained from each published study. We first note that all experiments, but one using the commercially-available BLI setup [30], were conducted using SPR with two configurations to perform the experiments: the first configuration consists in immobilizing the BMPs on the sensor chip while the second consists in immobilizing the BMPRs, this second strategy being the most common. In terms of immobilization protocols, we noted that several strategies were proposed, which can be grouped in three major categories (Table.SI.1): i) using biotinylated BMPR coupled to streptavidin-coated surfaces; ii) using BMPR-Fc captured on anti-Fc coated sensors and iii) direct immobilization of BMPR using an amine coupling strategy.

Looking at the published studies (Table.1 and Table SI.1), it appears from that for a given BMP/BMPR couple, the range of measured $K_{D}$ can be very broad. These discrepancies likely arise from the differences in experimental details, including immobilization strategies, experimental working conditions and the biochemistry of BMPs itself. Moreover, since BMP-2 and BMP-4 are usually considered to behave similarly [3], several studies were performed only on BMP-2 interaction with typeII BMPRs (BMPR-II, ACTR-IIA and ACTR-IIB) and with type-I BMPR ALK2, but there is no such study for BMP-4. We also noted a lack of data for the interactions of BMP-2, 4 and 7 with ALK1 since it was reported to be the major BMP-9 receptor [11]. Lastly, we noticed the absence of data on ALK5 (TGF $\beta R-I$ ) with any of the chosen BMPs, since it was traditionally considered solely as a TGF $\beta$ receptor [44] but was also shown to be a central point in BMP/TGF $\beta$ signaling [45]. 
bioRxiv preprint doi: https://doi.org/10.1101/2020.10.20.348060; this version posted October $21,2020$. The copyright holder for this preprint (which was not certified by peer review) is the author/funder, who has granted bioRxiv a license to display the preprint in perpetuity. It is made available under aCC-BY-NC-ND 4.0 International license.

\section{Dimeric state of BMPs and BMPR}

The commercially-available proteins that we used were produced in CHO for BMP-2, 7 and 9 or in E.coli for BMP-4. The BMPR coupled to Fc fragments (BMPR-Fc) were produced in mouse myeloma NS0 cells, except for ACTR-IIA that was produced in CHO cells. We verified the biochemical state (monomeric or dimeric) of all BMPs and BMPR-Fc by gel electrophoresis in both non-reducing and reducing conditions (Fig.SI.1). The BMPs were mostly dimeric, as expected [6], and migrate at $\approx 26$ $\mathrm{kDa}$ in non-reducing conditions, and at $\approx 13 \mathrm{kDa}$ in reducing conditions. Since the Fc fragment form dimers, the BMPR chimeras are also present in dimeric state and migrate at 90 and $110 \mathrm{kDa}$ in nonreducing condition and in a monomeric form with a band between 45 and $55 \mathrm{kDa}$ in reducing conditions (Fig.SI.1).

\section{Immobilization of BMPR on the biosensor}

In vivo, the BMPs are soluble proteins that localize in the extracellular matrix or in blood for BMP-9. They can then be considered to diffuse freely in a 3D space. The BMPRs are trans-membrane proteins that are localized at the cellular membrane and are thus diffusing in a 2D space. For this reason, it is likely that the order of magnitude of the diffusion of BMPR is similar to that of lipids in a membrane $(\approx$ $\left.1 \mu \mathrm{m}^{2} / \mathrm{s}\right)$ while that of BMPs is similar to a protein diffusing freely $\left(\approx 100 \mu \mathrm{m}^{2} / \mathrm{s}\right)$ [46]. We thus choose to immobilize the BMPRs at the biosensor surface and to adsorb BMPs at their surface to better mimic the in vivo situation.

In order to find a protocol applicable to all BMP/BMPR couples, we considered several capture strategies for BMPR immobilization at the biosensor surface. The same previously-published capture methods used for SPR, including biotinylated ligand/streptavidin surface, amine coupling absorption or Fc chimera/anti-human IgG or protein A surfaces were considered (Table.SI.1) [23-25,27]. Since all the BMPR-Fc chimeras were commercially-available, and since anti-Fc fragment-coated biosensors are known to more stable than protein A [30,35], we selected this strategy that consists in immobilizing the BMPR-Fc chimeras via the Fc dimer to the biosensor surfaces (Fig 1A and Material and methods). This configuration presents the advantage of immobilizing all of the BMPR homogeneously in one orientation, with their binding site accessible to BMPs.

In order to determine a suitable adsorption density of the BMPRs on the biosensors, we performed preliminary assays with ALK3 receptor immobilized at increasing densities leading to a signal between 0.5 to $3 \mathrm{~nm}$ of spectral shift (nm) after a fixed contact time of $150 \mathrm{~s}$. The functionalized surfaces were then set in contact with BMP-2 at a constant concentration of $5 \mathrm{nM}$ to proceed to BMP-2 adsorption (Fig.1B). As shown by the response at equilibrium vs. ALK3 concentration (FIG.1C), the optimal concentration of ALK3 is $\approx 28 \mathrm{nM}$, leading to an association signal of $\approx 0.5 \mathrm{~nm}$ after $600 \mathrm{~s}$.

\section{Interaction of BMPs with the BMPR-I and BMPR-II}

The kinetic interaction studies were then performed using the same protocol for the four BMPs with BMPRs. All BMPRs were adsorbed at densities corresponding to a spectral shift between 0.8 and 1.1 $\mathrm{nm}$. The BMP concentrations were varied over a large range ranging from $2 \mathrm{nM}$ to $80 \mathrm{nM}$ (Fig.2). Representative experimental curves for BMP-2/ALK3, BMP-9/ALK1, BMP-2/BMPR-II and BMP7/ACTR-IIA are shown in Fig.2 (respectively panel A-D).

To determine the kinetic parameters, the 1:1 Langmuir model binding model has been used. Indeed, it has been shown in structural studies $[23,25,47]$ that the BMP/BMP receptor interaction can be considered as bimolecular: It was reported that BMP dimers comprise two distinct pairs of binding sites: one for type-I BMPR and the other for type-II BMPR. While the type I interface is a large continuous area formed by residues from both BMP monomers, the interface with type II is composed only of amino-acids from one BMP monomer [5], as seen in the example of BMP-2/ALK3/ACTR-IIA (pdb: 2H64) [48] (Fig.3.A). Thus, a one to one binding is expected. Furthermore, the commonly-used 1:1 Langmuir model has always been used to date to fit the experimental data and to determine kinetics 
bioRxiv preprint doi: https://doi.org/10.1101/2020.10.20.348060; this version posted October 21,2020 . The copyright holder for this preprint (which was not certified by peer review) is the author/funder, who has granted bioRxiv a license to display the preprint in perpetuity. It is made available under aCC-BY-NC-ND 4.0 International license.

parameters $[23,26,49]$. In the present case, since the Fc chimera induces a dimerization of the BMPR, two possible binding modes are possible (Fig.3.B-E): one BMP molecule binding to two proximate BMPR binding domains (model B or D) or one BMP molecule binding to one BMPR binding domain (model C or E). Nonetheless, since BMP dimers are fully symmetrical, all binding models may lead to 1:1 binding kinetic. The $\mathrm{R}^{2}$ values of the fits, presented in tables SI.2 and SI.3, are in majority around 0.95 and higher which indicates an acceptable fit.

A fast association was generally observed for all the BMPs interacting with the type-I BMPR, but differences in the dissociation rate are seen. The association constant $\left(k_{a}\right)$ and dissociation constant $\left(k_{d}\right)$ that were extracted from the fit of each interaction curve are presented in Fig.4 as well as tables SI.2 and SI.3. BMP-2 and BMP-4 exhibit a high $\mathrm{k}_{\mathrm{a}}\left(\approx 15 \times 10^{5} \mathrm{M}^{-1} \cdot \mathrm{s}^{-1}\right.$ for BMP-2 and $\approx 5 \times 10^{5} \mathrm{M}^{-1} \cdot \mathrm{s}^{-1}$ for BMP-4), and low $\mathrm{k}_{\mathrm{d}}$ with both ALK3 and ALK6 $\left(\approx 0.5 \times 10^{-3} \mathrm{~s}^{-1}\right.$ for BMP-2 and $\approx 1.5 \times 10^{-3} \mathrm{~s}^{-1}$ for BMP-4), indicating a fast association and slow dissociation to these receptors. Furthermore, BMP-2 associates and dissociates in a similar manner to ALK1, ALK2, ALK5 $\left(\mathrm{k}_{\mathrm{a}} \approx 4 \times 10^{5} \mathrm{M}^{-1} \cdot \mathrm{s}^{-1}\right.$ and $\left.\mathrm{k}_{\mathrm{d}} \approx 3 \times 10^{-3} \mathrm{~s}^{-1}\right)$ and to the three type-II BMPRs ( $\mathrm{k}_{\mathrm{a}} \approx 11 \times 10^{5} \mathrm{M}^{-1} \cdot \mathrm{s}^{-1}$ and $\left.\mathrm{k}_{\mathrm{d}} \approx 6 \times 10^{-3} \mathrm{~s}^{-1}\right)$. In comparison to BMP-2, BMP-4 associates more slowly to these receptors.

BMP-7 demonstrates a slow association to all the type-I BMPRs $\left(\approx 2 \times 10^{5} \mathrm{M}^{-1} \cdot \mathrm{s}^{-1}\right)$, in addition to a slow association $\left(\approx 6 \times 10^{5} \mathrm{M}^{-1} \cdot \mathrm{s}^{-1}\right)$, and a slow dissociation $\left(\approx 2 \times 10^{-3} \mathrm{~s}^{-1}\right)$ to type-II BMPRs. Regarding BMP9 , it exhibits a fast association $\left(15.0 \pm 3.5 \times 10^{5} \mathrm{M}^{-1} . \mathrm{s}^{-1}\right)$ and a very slow dissociation $\left(0.2 \pm 0.1 \times 10^{-3} \mathrm{~s}^{-1}\right)$ to ALK1 and type-II BMPR $\left(\mathrm{k}_{\mathrm{a}} \approx 20 \times 10^{5} \mathrm{M}^{-1} \cdot \mathrm{s}^{-1}\right.$ and $\left.\mathrm{k}_{\mathrm{d}} \approx 3.3 \pm \times 10^{-3} \mathrm{~s}^{-1}\right)$. BMP-9 also presents a slow association and fast dissociation from ALK2 and ALK5 $\left(\mathrm{k}_{\mathrm{a}} \approx 2 \times 10^{5} \mathrm{M}^{-1} \cdot \mathrm{s}^{-1}\right.$ and $\left.\mathrm{k}_{\mathrm{d}} \approx 3 \times 10^{-3} \mathrm{~s}^{-1}\right)$, but it does not interact with ALK3 and ALK6.

Next, we calculated the equilibrium affinity constant $K_{D}$ (equal to the ratio of $k_{d}$ over $k_{a}$ ). BMPs present a generally high affinity to all BMPRs ranging from 133 to $0.2 \mathrm{nM}$ for high affinity interactions. The lowest $\mathrm{K}_{\mathrm{D}}$ values are highlighted in dark blue. BMP-2 and BMP-4 have a good binding affinity to both ALK3 and ALK6 since their $K_{\mathrm{D}}$ was $<3 \mathrm{nM}$ (Table.2A). They bind to ALK2 similarly with an affinity of $7.0 \pm 2.3 \mathrm{nM}$ for BMP-2 and $10.5 \pm 3.8 \mathrm{nM}$ for BMP-4. They also bind to ALK1 and ALK5 but BMP2 has a $\approx 4$-fold higher affinity to these receptors than BMP-4. Regarding type-II BMPRs, BMP-2 had a similar affinity for both ACTR-IIA and ACTR-IIB $(\approx 6 \mathrm{nM})$ while BMP-4 also interacted with both receptors although with $\approx 4$-fold lower affinity $(\approx 23 \mathrm{nM})$. In addition, BMP-2 has also a 10 -fold higher affinity for BMPR-II than BMP-4. We then investigated whether the differences between BMP-2 and BMP-4 may arise from their glycosylation state, since BMP-2 is produced in CHO while BMP-4, being produced in E-Coli, is non-glycosylated. We thus compared the interactions of ALK3 with both the glycosylated and non-glycosylated forms of BMP-4 (Fig.SI.2). For the glycosylated form of BMP-4, the increase in the non-specific signal was negligible $(\approx 0.02 \mathrm{~nm})$. However, the interactions differed slightly since $K_{D}$ was $1.32 \pm 0.48 \mathrm{nM}$ for the non-glycosylated BMP-4, versus $0.3 \pm 0.06 \mathrm{nM}$ for the glycosylated form.

BMP-7 interacts with all type-I BMPRs with similar affinities $(\approx 20 \mathrm{nM})$. In contrast, it has a greater affinity for the three type-II BMPRs as it binds to BMPR-II and ACTR-IIB similarly $(\approx 6 \mathrm{nM})$ and to ACTR-IIA with a 5 to 7 -fold higher affinity $(1.3 \pm 0.3 \mathrm{nM})$.

Regarding BMP-9, it binds ALK1 with high affinity $(0.2 \pm 0.1 \mathrm{nM})$, ALK5 and ALK2 with a much lower affinity $(51.0 \pm 18.3 \mathrm{nM}$ and $133.1 \pm 35.1 \mathrm{nM}$, respectively). The affinity of BMP-9 for all the three type-II BMPRs is high: $0.8 \pm 0.2 \mathrm{nM}$ for BMPR-II, $1.7 \pm 0.1 \mathrm{nM}$ for ACTR-IIA and $1.4 \pm 0.4 \mathrm{nM}$ for ACTR-IIB. Notably, BMP-9 affinity for BMPR-II is about 2-fold higher in comparison to ACTRIIA and ACTR-IIB.

Thus, the $K_{D}$ values indicated that there are significant differences between BMP-2 and BMP-4, a higher affinity of BMP-7 to type-I BMPRs in comparison to type-I BMPR, and a highly selective affinity of BMP-9 for ALK1 as well as to all type-II BMPRs.

In order to compare the BLI technique to SPR (Table.1), we performed SPR kinetic experiments for selected high affinity couples, namely BMP-9/ALK1 and BMP-2 or BMP-4/ALK3 or ALK2. For this 
purpose, we used commercially-available protein A-coated chips and BMPR-Fc chimera as adsorption strategy (Fig.5A). Unfortunately, the BMP-2/ALK3 (Fig.SI.3), BMP-2/ALK2, BMP-4/ALK3 (data not shown) kinetic interaction using this adsorption strategy could not be measured since non-specific binding to the sensor ship was too high and specific binding signal could not be resolved (Fig.SI.3). In contrast, the BMP-9/ALK1 interaction was notable and a $\mathrm{K}_{\mathrm{D}}$ of $13.4 \mathrm{pM}$ was obtained. This value is 15fold lower than obtained by BLI ( 200 nM - Fig.5B).

\section{Interaction of BMPs with the BMPR-I/BMPR-II ternary complex}

Next, we decided to investigate the interactions of BMP to type-I/type-II BMPR complexes. In vivo, It is reported that BMPs first bind to the inactive type-I BMPRs thus triggering type-II BMPRs to activate (by phosphorylation) the type-I BMPRs by forming a ternary complex [24,50]. We studied ALK2 as a type-I BMPR and all three type-II BMPRs with BMP-2, BMP-4 and BMP-7. We chose ALK2 since it is the most studied receptor and has a middle range affinity for the BMPs. Our experimental approach consisted in loading sequentially both types of BMP receptors on the biosensor (Fig.6A-B). We performed experiments using two capture strategies. Firstly, ALK2 was loaded, followed by a type-II BMPR and then BMP-2 was set into contact with the functionalized surfaces (Fig.6A). Secondly, a reverse sequence was used in which ACTR-IIB was captured first, followed by ALK2 and then BMP-2 (Fig.6B). The adsorption times were chosen such as to have an equivalent level of adsorption for each receptor, with a total shift being similar to the case of single BMP/BMPR interactions.

To process and fit the kinetic data, we initially applied a 1:1 Langmuir model but the fit was of poor quality (Fig.SI.4). These interactions consist of two different receptors and therefore possess two pairs of two distinct binding sites for type-I and type-II BMPRs. We thus presumed that both types of type-I and type-II receptors bind BMPs separately with different affinities and therefore applied a 2:1 heterogeneous binding model.

The $\mathrm{K}_{\mathrm{D}}$ in the configuration where ALK2 was immobilized first was $46.1 \pm 11.5 \mathrm{nM}$ for the first binding site and $14.4 \pm 2.3$ for the second. Conversely, when BMPR-II was adsorbed first the $\mathrm{K}_{\mathrm{D} 1}$ was $22.9 \pm$ $1.9 \mathrm{nM}$ and $\mathrm{K}_{\mathrm{D} 2} 4.6 \pm 0.2 \mathrm{nM}$ (Fig.6D). The same experiment was also performed for ALK2/BMPRII/BMP-7 resulting in a $\mathrm{K}_{\mathrm{D}}$ of $4.6 \pm 0.7 \mathrm{nM}$ and $19.1 \pm 6.4 \mathrm{nM}$ for the experiment where ALK2 was adsorbed first, compared to $5.4 \pm 0.2 \mathrm{nM}$ and $23.2 \pm 0.1 \mathrm{nM}$ for the reverse order. In the case of BMP7 , binding is similar whatever the order of receptor presentation.

The binding affinities for all the experiments where ALK2 is loaded first are summarized in Table.3. Surprisingly, we did not find any improvements in the $\mathrm{K}_{\mathrm{D}}$ when two receptors are captured on the biosensor surfaces compared to the situation when only one is present. The $\mathrm{K}_{\mathrm{D}}$ for all of the experiments appear to be higher than the $\mathrm{K}_{\mathrm{D}}$ of the simple BMP/BMPR interactions, indicating a lower affinity. In more details, the values of the two $K_{D}$ values may be attributed to the values of two different types of binary interaction (BMP/ALK2 or BMP/ type-II BMPR), such as the interaction BMP-7/ALK2/BMPRII where $\mathrm{K}_{\mathrm{D}} 1=4.6 \pm 0.7 \mathrm{nM}$ and $\mathrm{K}_{\mathrm{D}} 2=19.1 \pm 6.4 \mathrm{nM}$ (table.3), compared to $18.4 \pm 3.8 \mathrm{nM}$ for ALK2 and $5.5 \pm 1.2 \mathrm{nM}$ for BMPR-II in the binary experiments (Table.2). Nevertheless, this observation was not observed for other interactions. These results suggest the complexity of the interactions occurring on the surface.

\section{Discussion}

In this study, we performed experiments using the dimeric form of BMPs and BMPRs as confirmed by gel electrophoresis migration analysis (Fig.SI.1). Our aim in using dimers of BMPs and BMPRs was to mimic the in vivo interactions since BMPRs were reported to be homodimer or heterodimers (type-I BMPR/type-II BMPR) at the cell surface, in contrast to TGF $\beta$ R which appears to be homodimers in the absence of BMP-2 [51].

Using BLI, we quantified the binding affinities of the four BMPs with the eight different BMPRs in similar experimental conditions. As we showed with our SPR data, several BMPR/BMP couples 
bioRxiv preprint doi: https://doi.org/10.1101/2020.10.20.348060; this version posted October $21,2020$. The copyright holder for this preprint (which was not certified by peer review) is the author/funder, who has granted bioRxiv a license to display the preprint in perpetuity. It is made available under aCC-BY-NC-ND 4.0 International license.

(ALK3/BMP-2, ALK3/BMP-4 and ALK2/BMP-2) could not be analyzed by SPR using the same strategy as BLI with protein A coated sensors (Fig.SI.3), while BMP-9/ALK1 was detected (FIG.5). There may be non-specific adsorption of BMP-2 and 4 to protein A. The direct comparison of BLI versus SPR for the high affinity couple ALK1/BMP-9 showed that $\mathrm{K}_{\mathrm{D}}$ measured by BLI was 15 -fold lower than that measured by SPR (13.4 pM versus 200 pM) (Fig.5). These differences between both techniques may be explained by the physical and chemical differences of the techniques, since the thickness and composition of the sensor layers as well as the adsorption strategies are different. Another aspect to mention is the sensitivity of the method and the stability of the baseline signal, since the dissociation rate measured are sometimes at the limits of the instrument stability. Altogether, our experimental results show that the BLI technique is well adapted to gain quantitative information on a large range of BMP/BMPR couples.

To date, BMP-4 has barely been studied since it was often considered to exhibit a very close behavior to BMP-2 [5]. Our study first confirmed that both BMP-2 and BMP-4 bind to ALK3 and ALK6 with high affinity (Table.1), as already mentioned in the literature [6,30]. Additionally, our data reveals notable differences in the binding behaviors of BMP-2 and BMP-4. Indeed, BMP-2 binds to type-I BMPRs with a 3-fold higher affinity than BMP-4 (Table.2). Interestingly, the difference arises mainly from a difference in association rates to the receptors which was faster for BMP-2 than BMP-4, while the dissociation rates were similar (Fig.3). Notably, the strongest differences were observed for the typeII BMPR, with faster association rates for BMP-2 for all the three receptors, and faster dissociation rates for BMP-2 solely for BMRR-II and ACTR-IIA.

Our results are in agreement with previously published cellular data highlighting the distinct role of BMP-4 and BMP-2. One study examined their role in chondrocyte proliferation and found that the deletion of BMP-2 gene alone resulted in severe chondrodysplasia while the deletion of BMP-4 led to minor cartilage phenotype [52]. Likewise, a study using Xenopus embryos showed that the inhibition of BMP-4 or the use of a truncated ACTRII-A led to the similar phenotype for the formation of a secondary axis, while a defect in ACTRII-B caused an axial defect. As different phenotypes were observed, they concluded that BMP-4 does not transduce the biochemical signals via ACTR-IIB [53]. In acute myeloid leukemia, a distinct role of BMP-4 versus BMP-2 has been evidenced [54,55]: BMP-4 solely is involved as it activates a specific signaling pathway promoting immature resistant leukemic cells, which eventually leads to a relapse after treatment [54,55]. Furthermore, it has been demonstrated that BMP-4 mainly stimulated hematopoietic stem cell proliferation, differentiation and homing [56,57]. To note, these experimental results are not confirmed by structural data, although a study has shown that the crystal structures of the ternary complexes of BMP-2/ALK3/ACTR-IIA and BMP-2/ALK3/ACTR-IIB do not present significant structural differences [21]. In view of our findings regarding the specific differences between BMP-2 and BMP-4, it will be interesting to further evaluate their effects in different cell signaling contexts.

It is also noteworthy that the average binding of all BMPs $(-2,4,7,9)$ to ALK2 is in the same range $\approx$ 7-10 nM. In addition to the lower affinity of BMP-2 for type-II BMPRs compared to type-I BMPRs, we observed faster kinetic constants ( $\mathrm{k}_{\mathrm{a}}, \mathrm{k}_{\mathrm{d}}$ ) for type-II BMPRs (Fig.3). This observation was previously reported and assumed to be the reason why BMP-2 and BMP-4 are recruited in a sequential order, with an initial binding to the higher affinity type-I BMPRs [21]. It may be interesting to further study BMP/ALK2 interactions in the context of the R206H mutation, which is associated to Fibrodysplasia Ossificans Progressiva (FOP): this mutation leads to the activation of BMP signaling in the absence of BMP and to an enhanced biochemical signal in the presence of BMP [58].

Our results showed that BMP-7 binds similarly to all ALKs with an affinity of $\approx 20 \mathrm{nM}$, in agreement with the literature review (Table.1), although the range of previously-reported $K_{D}$ was large. With respect to type-II BMPRs, we found that BMP-7 binds with high affinities to the three type-II BMPRs, with a 5-fold higher affinity for ACTR-IIA (Table.2B). A previous study reported that BMP-7 signals through ACTR-IIA [59]. Notably, BMP-7 was also reported to induce chemotaxis in monocytic cells through BMPR-II and ACTR-IIA receptors, but not through ACTR-IIB [60]. 
bioRxiv preprint doi: https://doi.org/10.1101/2020.10.20.348060; this version posted October 21,2020 . The copyright holder for this preprint (which was not certified by peer review) is the author/funder, who has granted bioRxiv a license to display the preprint in perpetuity. It is made available under aCC-BY-NC-ND 4.0 International license.

Previous studies on BMP-9 have shown that it binds to ALK1 and ALK5 in endothelial cells [61-63], and to ALK1 and ALK2 in mesenchymal cells used for osteogenic differentiation [64]. Our data showing that BMP-9 binds ALK1 with a high affinity $(0.2 \pm 0.1 \mathrm{nM})$ and ALK2/ALK5 with a lower affinity $(133.1 \pm 35.1 \mathrm{nM}$ and $51.0 \pm 18.3 \mathrm{nM}$, respectively) (Table.2A) indicated that all these three ALK receptors are important in the signaling of BMP-9. The comparison of the structural data between both complexes BMP-2/ALK3-ECD/ACTR-2B-ECD and BMP-9/ALK1-ECD/ACTR-2B-ECD shows that ALK1 has a distinct interface with BMP-9, and presents several structural differences, compared to other type-I BMPRs. These structural disparities may well explain the low affinity of ALK1 for all the other BMPs [35], as seen in our data. Regarding the type-II BMPRs, former studies have shown that BMP-9 can bind to all of them [61,65]. Our results indicated that BMP-9 bound all type-II BMPR with a very high affinity ( $\sim 0.8$ to $1.7 \mathrm{nM})$ and with a slightly higher affinity for BMPR-II $(0.8 \pm 0.2 \mathrm{nM})$ (Table.2), in concert with the literature $[35,36]$ (Table.SI.1).

Interestingly, our results showed that there is a binding of several BMPs to ALK5 (Fig 4 and Table.2A). We observed average affinities of BMP-2 (5.8 $\pm 1.1 \mathrm{nM})$, BMP-4 $(21.9 \pm 6.6 \mathrm{nM})$ and BMP-7 (22.6 \pm $1.1 \mathrm{nM}$ ) to ALK5. Although ALK5 was considered to be mainly a TGF $\beta$ R, our data show that several BMPs can bind to ALK5, which highlights its possible role in the BMP signaling pathway. Indeed, ALK5 was shown to inhibit BMP signaling mediated by ALK1 in the growth plate of cartilage [66]. It was also shown that different signaling through ALK1 and ALK5 regulate leptin expression in mesenchymal stem cells [16]. Last but not least, BMP-2 induces complex formation between ALK3 and ALK5 in cancer cells [45]. Further in vivo studies should aim to unravel a possible crosstalk between TGF $\beta /$ BMP pathways mediated by ALK5.

The use of a 2:1 heterogeneous ligand model to analyze the ternary complex interactions did not yield any improvement in the binding affinity compared to the bimolecular BMP/BMPR interactions, although such mechanism of cooperativity has been proposed. It was reported that BMP-7 affinity to ALK2 increases in the presence of ACTR-IIA [24,67]. Nonetheless, our data do not show any cooperativity between both types of BMPRs. This result agrees with the literature since a previous SPR study of BMP-7/ALK3/ACTR-IIA using a BMPR mix similarly reported limitation of the system in observing a cooperativity [28].

Our study highlighted the specific differences in BMP/BMPR interactions that could pave the way for future BMP signaling studies, with respect to BMP/TGF $\beta$ crosstalk and to the type of signaling pathway (SMAD versus non-SMAD) and to the specificities of the receptor (type I versus type II).

\section{Experimental procedures}

\section{Protein and reagents}

All used BMPs and extracellular domains (ECD) of the BMPR-FC chimeras were bought from Sigma Aldrich (Missouri, USA) and R\&D systems (Minnesota, USA) respectively. BMP-2 and BMP-7 and BMP-9 are produced in Chinese hamster ovary (CHO) cells while BMP-4 was produced in Escherichia coli. The Anti-hIgG Fc (AHC) capture biosensors were purchased from ForteBio (California, USA) and the protein A coated chips were purchased from GE Healthcare Life Sciences. The buffer was made of $20 \mathrm{mM}$ HEPES at pH 7.4 with $150 \mathrm{mM} \mathrm{NaCl}$ (name hereafter Hepes- $\mathrm{NaCl}$ ) and $0.02 \%$ tween while the regeneration buffer was made of $10 \mathrm{mM}$ glycine at $\mathrm{pH} 1.7$ (named hereafter regeneration buffer). They were all prepared in-house.

\section{Kinetics interaction experiments}

All the BLI experiments were performed using an OctetRED96e apparatus from Pall/FortéBio (California, U.S) and data were recorded with the manufacturer software (Data Acquisition v11.11). All proteins were solubilized following the supplier instruction in Hepes-NaCl buffer. The analysis protocol was adapted from previous studies [30,35]. In details, prior any capture, the BMPR-Fc samples were first diluted in the Hepes- $\mathrm{NaCl}$ buffer. For the association phase, the BMPs were diluted in 2-fold 
serial dilutions in Hepes- $\mathrm{NaCl}$ buffer. $0.2 \mathrm{ml}$ of each sample and buffer were disposed in wells of black 96-well plates (Nunc F96 MicroWell, Thermo Fisher Scientific), maintained at $25^{\circ} \mathrm{C}$ and agitated at 1000 r.p.m. the whole time. Prior each assay, all biosensors were pre-wetted in $0.2 \mathrm{ml}$ of Hepes-buffer for $10 \mathrm{~min}$, followed by monitored equilibration for 60 or $120 \mathrm{~s}$. Anti-hIgG Fc (AHC) capture biosensors (FortéBio) were loaded with each ligand for $200 \mathrm{~s}$ until to reach a spectrum shift between 0.8 and $1.1 \mathrm{~nm}$ depending of BMPR-Fc, followed by an additional equilibration step of $60 \mathrm{~s}$ or $120 \mathrm{~s}$ in Hepes- $\mathrm{NaCl}$ buffer. Association phases were monitored during dipping the functionalized biosensors in analyte solutions of different concentrations between 2 and $80 \mathrm{nM}$ for $400 \mathrm{~s}$, and the dissociation phases in the buffer for $400 \mathrm{~s}$. To assess and monitor analyte unspecific binding, blank biosensors were treated with the same procedures but replacing the ligand solutions by analysis buffer. All sensors were fully regenerated between experiments with different BMPRs by dipping for 30s in regeneration buffer. All measurements were performed three times in independent experiments.

Kinetics data were analyzed using the manufacturer software (Data analysis HT v11.1). The "blank" signal from the biosensor in the presence of the Hepes-NaCl buffer was subtracted from the signal obtained from each functionalized biosensor and each analyte concentration. The kinetic signals were then fitted using a global/local method and 1:1 Langmuir or 2:1 heterogeneous ligand model. Affinity constants were calculated from the ratio $k_{d} / k_{a}$ values. The reported values are given as mean $\pm S D$ obtained from three independent experiments.

\section{Surface plasmon resonance experiments}

All surface plasmon resonance experiments were performed using a Biacore T200 apparatus (GE Healthcare Life Sciences/Biacore, Illinois, U.S) and data were recorded using the manufacturer software (Biacore control software v2.0). All protein samples were solubilized following the supplier instruction in analysis buffer prior any experiment. Prior to capture, the BMPR-Fc samples were first diluted in analysis buffer. For association phase, BMP samples were diluted at concentration between 0.2 and $6.4 \mathrm{nM}$ in 2-fold serial dilutions in the Hepes- $\mathrm{NaCl}$ buffer. Sensor chips and system were preequilibrated in Hepes-NaCl buffer prior any injection. The protein A sensor chips (GE Healthcare Lifesciences) were loaded by injecting each ligand for $100 \mathrm{~s}$ until to reach a signal level between 100 and 120 arbitrary response units (R.U.) depending of BMPR-Fc, followed by an additional equilibration step of several minutes in analysis buffer. Association phases were monitored during injections over the functionalized surfaces of analyte solutions of different concentrations for $300 \mathrm{~s}$, and the dissociation phases of analysis buffer for $300 \mathrm{~s}$. To assess and monitor analyte unspecific binding, blank surfaces were treated with the same procedures but replacing the ligand solutions by analysis buffer. All surfaces were fully regenerated between experiments with different BMPR-Fc by injecting for 30s regeneration buffer. Two independent experiments were performed. Kinetic data were processed with the manufacturer software (Biacore Evaluation software v3.1). Signals from the reference surface were subtracted from the signals obtained from each functionalized ship. Resulting specific kinetics signals were then fitted using the 1:1 Langmuir model. Affinity constants were calculated from the ratio $\mathrm{k}_{\mathrm{d}} / \mathrm{k}_{\mathrm{a}}$ values. Reported values are obtained by averaging the values obtained from the replicates and reported errors as the standard deviation.

\section{Author contributions}

C.P conceived the idea. C.P, P.M, VK and E.M designed the experiments. V.K and P.M performed the experiments and collected the data. VK, P.M, C.P and J.B.R analyzed the data. C.P acquired the funding. V.K., P.M, J.B.R and CP wrote the manuscript. E.M. reviewed and edited the manuscript. 


\section{Acknowledgments}

The authors acknowledge Anne Chouquet from the ISBG platform for her help and Marianne Weidenhaupt (INPG) for discussions regarding the immobilization protocol. We are grateful to Sabine Bailly and Corinne Albiges-Rizo for fruitful discussions and advices.

\section{Funding and additional information}

The study was supported by Agence Nationale de la Recherche (ANR CODECIDE, ANR-17-CE13022) to C.P and by the Fondation Recherche Medicale (FRM, grant DEQ20170336746) to C.P. VK was supported by a PhD fellowship from Grenoble Institute of Technology. This work used the platforms from Grenoble Instruct-ERIC Center (ISBG: UMS 3518 CNRS-CEA-UGA-EMBL), within the Grenoble Partnership for Structural Biology (PSB), supported by FRISBI (ANR-10-INBS-05-02) and GRAL, financed within the University Grenoble Alpes graduate school (Ecoles Universitaires de Recherche) CBH-EUR-GS (ANR-17-EURE-0003).

\section{Supporting information}

SI TABLE 1. Detailed literature study table summarizing the $\mathrm{K}_{\mathrm{D}}(\mathrm{nM})$ of the BMP/type-I and type-II BMPR interaction couples.

SI FIGURE 1. Image of a gel electrophoresis showing all the used BMPs, ALKs and type-II BMPR.

SI TABLE 2. Detailed kinetic tables indicating the $K_{D}(n M), k_{a}\left(M^{-1} \cdot s^{-1}\right), k_{d}\left(s^{-1}\right)$ and $R^{2}$ of the BMP/typeI interaction couples.

SI TABLE 3. Detailed kinetic tables indicating the $K_{D}(n M), k_{a}\left(M^{-1} \cdot s^{-1}\right), k_{d}\left(s^{-1}\right)$ and $R^{2}$ of the BMP/typeII interaction couples.

SI FIGURE 2. Binding kinetics between non-glycosylated and glycosylated BMP-4 with ALK3.

SI FIGURE 3. SPR binding curve for BMP-2/ALK3.

SI FIGURE 4. BLI binding kinetics of BMP-2 with ALK2 and ACTR-IIB in two confirmations using $1: 1$ fit. 


\section{References}

1 Sieber C, Kopf J, Hiepen C \& Knaus P (2009) Recent advances in BMP receptor signaling. Cytokine Growth Factor Rev 20, 343-355.

2 Wang RN, Green J, Wang Z, Deng Y, Qiao M, Peabody M, Zhang Q, Ye J, Yan Z, Denduluri S, Idowu O, Li M, Shen C, Hu A, Haydon RC, Kang R, Mok J, Lee MJ, Luu HL \& Shi LL (2014) Bone Morphogenetic Protein (BMP) signaling in development and human diseases. Genes Dis 1, 87105.

3 Ehata S, Yokoyama Y, Takahashi K \& Miyazono K (2013) Bi-directional roles of bone morphogenetic proteins in cancer: Another molecular Jekyll and Hyde? Pathol Int 63, 287-296.

4 Kishigami S \& Mishina Y (2005) BMP signaling and early embryonic patterning. Cytokine Growth Factor Rev 16, 265-278.

5 Miyazono K, Kamiya Y \& Morikawa M (2010) Bone morphogenetic protein receptors and signal transduction. J Biochem 147, 35-51.

6 Mueller TD \& Nickel J (2012) Promiscuity and specificity in BMP receptor activation. FEBS Lett 586, 1846-1859.

7 Marshall R. Urist (1965) Bone: Formation by autoinduction. Class Pap Orthop, 449-451.

8 Santo VE, Gomes ME, Mano JF \& Reis RL (2013) Controlled release strategies for bone, cartilage, and osteochondral engineering-part $\mathrm{i}$ : Recapitulation of native tissue healing and variables for the design of delivery systems. Tissue Eng - Part B Rev 19, 308-326.

9 Busch C \& Wheadon H (2019) Bone marrow niche crosses paths with BMPs: A road to protection and persistence in CML. Biochem Soc Trans 47, 1307-1325.

10 Grgurevic L, Christensen GL, Schulz TJ \& Vukicevic S (2016) Bone morphogenetic proteins in inflammation, glucose homeostasis and adipose tissue energy metabolism. Cytokine Growth Factor Rev 27, 105-118.

11 Nicholas W. Morrell, Donald B. Bloch, Peter ten Dijke, Marie-Jose T.H. Goumans, Akiko Hata, Jim Smith, Paul B. Yu and KDB (2016) Targeting BMP signalling in cardiovascular disease and anaemia. Physiol Nat Rev Cardiol Behav 13, 106-120.

12 Jiramongkolchai P, Owens P \& Hong CC (2016) Emerging roles of the bone morphogenetic protein pathway in cancer: Potential therapeutic target for kinase inhibition. Biochem Soc Trans 44, 11171134.

13 Miyazono K, Kusanagi K \& Inoue H (2001) Divergence and convergence of TGF- $\beta$ /BMP signaling. J Cell Physiol 187, 265-276.

14 Carvalho D, Taylor KR, Olaciregui NG, Molinari V, Clarke M, Mackay A, Ruddle R, Henley A, Valenti M, Hayes A, Brandon ADH, Eccles SA, Raynaud F, Boudhar A, Monje M, Popov S, Moore AS, Mora J, Cruz O, Vinci M, Brennan PE, Bullock AN, Carcaboso AM \& Jones C (2019) ALK2 inhibitors display beneficial effects in preclinical models of ACVR1 mutant diffuse intrinsic pontine glioma. Commun Biol 2.

15 Zylbersztejn F, Flores-Violante M, Voeltzel T, Nicolini FE, Lefort S \& Maguer-Satta V (2018) The BMP pathway: A unique tool to decode the origin and progression of leukemia. Exp Hematol 61, 36-44.

16 Zeddou M, Relic B, Malaise O, Charlier E, Desoroux A, Beguin Y, De Seny D \& Malaise MG (2012) Differential signalling through ALK-1 and ALK-5 regulates leptin expression in mesenchymal stem cells. Stem Cells Dev 21, 1948-1955.

17 Hiepen C, Jatzlau J, Hildebrandt S, Kampfrath B, Goktas M, Murgai A, Cuellar Camacho JL, Haag R, Ruppert C, Sengle G, Cavalcanti-Adam EA, Blank KG \& Knaus P (2019) BMPR2 acts as a gatekeeper to protect endothelial cells from increased TGF $\beta$ responses and altered cell mechanics.

18 Lowery JW \& Rosen V (2018) The BMP pathway and its inhibitors in the skeleton. Physiol Rev 98, 2431-2452.

19 Yadin D, Knaus P \& Mueller TD (2016) Structural insights into BMP receptors: Specificity, activation and inhibition. Cytokine Growth Factor Rev 27, 13-34.

20 Sanchez-Duffhues G, Williams E, Goumans MJ, Heldin CH \& ten Dijke P (2020) Bone morphogenetic protein receptors: Structure, function and targeting by selective small molecule kinase inhibitors. Bone 138. 
bioRxiv preprint doi: https://doi.org/10.1101/2020.10.20.348060; this version posted October $21,2020$. The copyright holder for this preprint (which was not certified by peer review) is the author/funder, who has granted bioRxiv a license to display the preprint in perpetuity. It is made available under aCC-BY-NC-ND 4.0 International license.

21 Nickel J \& Mueller TD (2019) Specification of BMP Signaling. Cells 8, 1579.

22 Aykul S \& Martinez-hackert E (2016) Transforming Growth Factor- Family Ligands Can Function as Antagonists by Competing for Type II Receptor Binding. 291, 10792-10804.

23 Kirsch T, Nickel J \& Sebald W (2000) BMP-2 antagonists emerge from alterations in the low-affinity binding epitope for receptor BMPR-II. EMBO J 19, 3314-3324.

24 Greenwald J, Groppe J, Gray P, Wiater E, Kwiatkowski W, Vale W \& Choe S (2003) The BMP7/ActRII extracellular domain complex provides new insights into the cooperative nature of receptor assembly. Mol Cell 11, 605-617.

25 Allendorph GP, Vale WW \& Choe S (2006) Structure of the ternary signaling complex of a TGFbeta superfamily member. Proc Natl Acad Sci 103, 7643-7648.

26 Allendorph GP, Isaacs MJ, Kawakami Y, Belmonte JCI \& Choe S (2007) BMP-3 and BMP-6 structures illuminate the nature of binding specificity with receptors. Biochemistry 46, 1223812247.

27 Kotzsch A, Nickel J, Seher A, Heinecke K, Van Geersdaele L, Herrmann T, Sebald W, Mueller TD, Geersdaele L Van, Herrmann T, Sebald W \& Mueller TD (2008) Structure analysis of bone morphogenetic protein-2 type I receptor complexes reveals a mechanism of receptor inactivation in juvenile polyposis syndrome. $J$ Biol Chem 283, 5876-5887.

28 Heinecke K, Seher A, Schmitz W, Mueller TD, Sebald W \& Nickel J (2009) Receptor oligomerization and beyond: A case study in bone morphogenetic proteins. BMC Biol 7, 59.

29 Yamawaki K, Kondo Y, Okada T, Oshima T, Kakitani M \& Tomizuka K (2016) The soluble form of BMPRIB is a novel therapeutic candidate for treating bone related disorders. Sci Rep 6, 3-6.

30 Seeherman HJ, Berasi SP, Brown CT, Martinez RX, Sean Juo Z, Jelinsky S, Cain MJ, Grode J, Tumelty KE, Bohner M, Grinberg O, Orr N, Shoseyov O, Eyckmans J, Chen C, Morales PR, Wilson CG, Vanderploeg EJ \& Wozney JM (2019) A BMP/activin A chimera is superior to native BMPs and induces bone repair in nonhuman primates when delivered in a composite matrix. Sci Transl Med 11, 1-21.

31 Saremba S, Nickel J, Seher A, Kotzsch A, Sebald W \& Mueller TD (2007) Type I receptor binding of bone morphogenetic protein 6is dependent on N-glycosylation of the ligand. FEBS J 12, 172183.

32 Mahlawat P, Ilangovan U, Biswas T, Sun LZ \& Hinck AP (2012) Structure of the Alk1 extracellular domain and characterization of its bone morphogenetic protein (BMP) binding properties. Biochemistry 51, 6328-6341.

33 Hatta T, Konishi H, Katoh E, Natsume T, Ueno N, Kobayashi Y \& Yamazaki T (2000) Identification of the ligand-binding site of the BMP type IA receptor for BMP-4. Biopolym - Pept Sci Sect 55, 399-406.

34 Szláma G, Kondás K, Trexler M \& Patthy L (2010) WFIKKN1 and WFIKKN2 bind growth factors TGF $\beta$ 1, BMP2 and BMP4 but do not inhibit their signalling activity. FEBS $J$ 277, 5040-5050.

35 Townson SA, Martinez-Hackert E, Greppi C, Lowden P, Sako D, Liu J, Ucran JA, Liharska K, Underwood KW, Seehra J, Kumar R \& Grinberg A V. (2012) Specificity and structure of a high affinity activin receptor-like kinase 1 (ALK1) signaling complex. J Biol Chem 287, 27313-27325.

36 Kienast Y, Jucknischke U, Scheiblich S, Thier M, De Wouters M, Haas A, Lehmann C, Brand V, Bernicke D, Honold K \& Lorenz S (2016) Rapid activation of bone morphogenic protein 9 by receptor-mediated displacement of pro-domains. J Biol Chem 291, 3395-3410.

37 Salmon RM, Guo J, Wood JH, Tong Z, Beech JS, Lawera A, Yu M, Grainger DJ, Reckless J, Morrell NW \& Li W (2020) Molecular basis of ALK1-mediated signalling by BMP9/BMP10 and their prodomain-bound forms. Nat Commun 11, 1-16.

38 Hänel C \& Gauglitz G (2002) Comparison of reflectometric interference spectroscopy with other instruments for label-free optical detection. Anal Bioanal Chem 372, 91-100.

39 Gauglitz G (2020) Critical assessment of relevant methods in the field of biosensors with direct optical detection based on fibers and waveguides using plasmonic, resonance, and interference effects. Anal Bioanal Chem 412, 3317-3349.

40 Abdiche Y, Malashock D, Pinkerton A \& Pons J (2008) Determining kinetics and affinities of protein interactions using a parallel real-time label-free biosensor, the Octet. Anal Biochem 377, 209-217.

41 Sultana A \& Lee JE (2015) Measuring protein-protein and protein-nucleic acid interactions by biolayer interferometry. Curr Protoc Protein Sci 2015, 19.25.1-19.25.26. 
bioRxiv preprint doi: https://doi.org/10.1101/2020.10.20.348060; this version posted October $21,2020$. The copyright holder for this preprint (which was not certified by peer review) is the author/funder, who has granted bioRxiv a license to display the preprint in perpetuity. It is made available under aCC-BY-NC-ND 4.0 International license.

42 Frenzel D \& Willbold D (2014) Kinetic titration series with biolayer interferometry. PLoS One 9, 17.

43 Wagner DO, Sieber C, Bhushan R, Börgermann JH, Graf D \& Knaus P (2010) BMPs: From bone to body morphogenetic proteins. Sci Signal 3.

44 Massagué J (1998) TGF- $\beta$ SIGNAL TRANSDUCTION. Annu rev Biochem 67.

45 Holtzhausen A, Golzio C, How T, Lee YH, Schiemann WP, Katsanis N \& Blobe GC (2014) Novel bone morphogenetic protein signaling through Smad2 and Smad3 to regulate cancer progression and development. FASEB J 28, 1248-1267.

46 Blin G, Margeat E, Carvalho K, Royer CA, Roy C \& Picart C (2008) Quantitative analysis of the binding of ezrin to large unilamellar vesicles containing phosphatidylinositol 4,5 bisphosphate. Biophys J 94, 1021-1033.

47 Isaacs MJ, Kawakami Y, Allendorph GP, Yoon BH, Izpisua Belmonte JC \& Choe S (2010) Bone morphogenetic protein-2 and -6 heterodimer illustrates the nature of ligand-receptor assembly. Mol Endocrinol 24, 1469-1477.

48 Weber D, Kotzsch A, Nickel J, Harth S, Seher A, Mueller U, Sebald W \& Mueller TD (2007) A silent H-bond can be mutationally activated for high-affinity interaction of BMP-2 and activin type IIB receptor. BMC Struct Biol 7, 1-20.

49 Greenwald J, Le V, Corrigan A, Fischer W, Komives E, Vale W \& Choe S (1998) Characterization of the extracellular ligand-binding domain of the type II activin receptor. Biochemistry 37, 1671116718.

50 Ehrlich M, Gutman O, Knaus P \& Henis YI (2012) Oligomeric interactions of TGF- $\beta$ and BMP receptors. FEBS Lett 586, 1885-1896.

51 Gilboa L, Nohe A, Geissendo T, Sebald W, Henis YI \& Knaus P (2000) Bone Morphogenetic Protein Receptor Complexes on the Surface of Live Cells : A New Oligomerization Mode for Serine / Threonine Kinase Receptors. Mol Biol Cell 11, 1023-1035.

52 Shu B, Zhang M, Xie R, Wang M, Jin H, Hou W, Tang D, Harris SE, Mishina Y, O’Keefe RJ, Hilton MJ, Wang Y \& Chen D (2011) BMP2, but not BMP4, is crucial for chondrocyte proliferation and maturation during endochondral bone development. J Cell Sci 124, 3428-3440.

53 New H V., Kavka AI, Smith JC \& Green JBA (1997) Differential effects on Xenopus development of interference with type IIA and type IIB activin receptors. Mech Dev 61, 175-186.

54 Voeltzel T, Flores-Violante M, Zylbersztejn F, Lefort S, Billandon M, Jeanpierre S, Joly S, Fossard G, Milenkov M, Mazurier F, Nehme A, Belhabri A, Paubelle E, Thomas X, Michallet M, Louache F, Nicolini FE, Caron de Fromentel C \& Maguer-Satta V (2018) A new signaling cascade linking BMP4, BMPR1A, $\triangle \mathrm{Np} 73$ and NANOG impacts on stem-like human cell properties and patient outcome. Cell Death Dis 9.

55 Lefort S \& Maguer-Satta V (2020) Targeting BMP signaling in the bone marrow microenvironment of myeloid leukemia. Biochem Soc Trans 48, 411-418.

56 Bhatia M, Bonnet D, Wu D, Murdoch B, Wrana J, Gallacher L \& Dick JE (1999) Bone morphogenetic proteins regulate the developmental program of human hematopoietic stem cells. J Exp Med 189, 1139-1147.

57 Khurana S, Buckley S, Schouteden S, Ekker S, Petryk A, Delforge M, Zwijsen A \& Verfaillie CM (2013) A novel role of BMP4 in adult hematopoietic stem and progenitor cell homing via Smad independent regulation of integrin- $\alpha 4$ expression. Blood 121, 781-790.

58 Kaplan FS, Seemann P, Haupt J, Xu M, Lounev VY, Mullins M \& Shore EM (2010) Investigations of Activated ACVR1/ALK2, a Bone Morphogenetic Protein Type I Receptor, That Causes Fibrodysplasia Ossificans Progressiva. Methods Enzymol 484, 357-373.

59 Lavery K, Swain P, Falb D \& Alaoui-Ismaili MH (2008) BMP-2/4 and BMP-6/7 differentially utilize cell surface receptors to induce osteoblastic differentiation of human bone marrow-derived mesenchymal stem cells. J Biol Chem 283, 20948-20958.

60 Perron JC \& Dodd J (2009) ActRIIA and BMPRII type II BMP receptor subunits selectively required for Smad4-independent BMP7-evoked chemotaxis. PLoS One 4.

61 Scharpfenecker M, van Dinther M, Liu Z, van Bezooijen RL, Zhao Q, Pukac L, Löwik CWGM \& ten Dijke P (2007) BMP-9 signals via ALK1 and inhibits bFGF-induced endothelial cell proliferation and VEGF-stimulated angiogenesis. J Cell Sci 120, 964-972.

62 David L, Mallet C, Mazerbourg S, Feige JJ \& Bailly S (2007) Identification of BMP9 and BMP10 
bioRxiv preprint doi: $\mathrm{https}$ //doi.org/10.1101/2020.10.20.348060; this version posted October 21, 2020. The copyright holder for this preprint (which was not certified by peer review) is the author/funder, who has granted bioRxiv a license to display the preprint in perpetuity. It is made available under aCC-BY-NC-ND 4.0 International license.

as functional activators of the orphan activin receptor-like kinase 1 (ALK1) in endothelial cells. Blood 109, 1953-1961.

63 Ray BN, Lee NY, How T \& Blobe GC (2010) ALK5 phosphorylation of the endoglin cytoplasmic domain regulates Smad1/5/8 signaling and endothelial cell migration. Carcinogenesis 31, 435441.

64 Luo J, Tang M, Huang J, He BC, Gao JL, Chen L, Zuo GW, Zhang W, Luo Q, Shi Q, Zhang BQ, Bi Y, Luo X, Jiang W, Su Y, Shen J, Kim SH, Huang E, Gao Y, Zhou JZ, Yang K, Luu HH, Pan X, Haydon RC, Deng ZL \& He TC (2010) TGFß/BMP type I receptors ALK1 and ALK2 are essential for BMP9-induced osteogenic signaling in mesenchymal stem cells. J Biol Chem 285, 2958829598.

65 Brown MA, Zhao Q, Baker KA, Naik C, Chen C, Pukac L, Singh M, Tsareva T, Parice Y, Mahoney A, Roschke V, Sanya I \& Choe S (2005) Crystal structure of BMP-9 and functional interactions with pro-region and receptors. $J$ Biol Chem 280, 25111-25118.

66 Wang W, Chun H, Baek J, Sadik JE, Shirazyan A, Razavi P, Lopez N \& Lyons KM (2019) The TGF $\beta$ type i receptor TGF $\beta R I$ functions as an inhibitor of BMP signaling in cartilage. Proc Natl Acad Sci U S A 116, 15570-15579.

67 Sebald W \& Mueller TD (2003) The interaction of BMP-7 and ActRII implicates a new mode of receptor assembly. Trends Biochem Sci 28, 518-521.

\section{TABLES}

TABLE 1. Literature study of all the $K_{D}(n M)$ of the interactions between couples of BMP and their receptors (BMPR of type I and type II). The experiments were usually performed in one of the two configurations: in red, when the BMPR is immobilized and in blue, when the BMP is immobilized. 
bioRxiv preprint doi: https://doi.org/10.1101/2020.10.20.348060; this version posted October 21, 2020. The copyright holder for this preprint (which was not certified by peer review) is the author/funder, who has granted bioRxiv a license to display the preprint in perpetuity. It is made available under aCC-BY-NC-ND 4.0 International license.

\begin{tabular}{|c|c|c|c|c|c|c|c|c|c|c|}
\hline $\begin{array}{c}\mathrm{K}_{\mathrm{D}} \\
(\mathrm{nM})\end{array}$ & Confo. & Tech. & ALK1 & $\begin{array}{c}\text { ALK2 } \\
\text { (ActR-I) }\end{array}$ & $\begin{array}{c}\text { ALK3 } \\
\text { (BMPR-IA) }\end{array}$ & $\begin{array}{c}\text { ALK5 } \\
\text { (TGF } \beta \text { R-I) }\end{array}$ & $\begin{array}{c}\text { ALK6 } \\
\text { (BMPR-IB) }\end{array}$ & BMPR-II & ActR-IIA & ActR-IIB \\
\hline \multirow{2}{*}{ BMP-2 } & $\begin{array}{c}\text { BMPR } \\
\text { immobilized }\end{array}$ & $\begin{array}{l}\text { SPR } \\
\text { BLI }\end{array}$ & & & $\begin{array}{c}0.004-2.6^{23,26-29} \\
1.1^{30}\end{array}$ & & $\begin{array}{l}2.5-11^{23,27-29} \\
1.1^{30}\end{array}$ & \begin{tabular}{|c|}
$45-100^{23,28}$ \\
$26.7^{30}$
\end{tabular} & $\begin{array}{l}14-80^{23-26,28} \\
52.7^{30}\end{array}$ & $\begin{array}{c}6-36^{26-28} \\
8^{30}\end{array}$ \\
\hline & $\begin{array}{c}\text { BMP } \\
\text { immobilized }\end{array}$ & SPR & & $>400000^{31}$ & $10-330^{28,31,32}$ & & $95-350^{28,31}$ & & $3800-5400^{24,31}$ & \\
\hline \multirow{2}{*}{ ВMP-4 } & $\begin{array}{c}\text { BMPR } \\
\text { immobilized }\end{array}$ & SPR & & & $0.06^{29}$ & & $0.22^{29}$ & & & \\
\hline & $\begin{array}{c}\text { BMP } \\
\text { immobilized }\end{array}$ & SPR & & & $1.2-47^{33,34}$ & & & & & \\
\hline \multirow{2}{*}{ ВМP-7 } & \begin{tabular}{|c|} 
BMPR \\
immobilized
\end{tabular} & SPR & & $>500^{28}$ & $2-1680^{26,28,29}$ & & $0.3-9^{28,29}$ & $25^{28}$ & $1-5.1^{24-26,28}$ & $6-7^{26,28}$ \\
\hline & $\begin{array}{c}\text { BMP } \\
\text { immobilized }\end{array}$ & SPR & & $55000-143000^{24,31}$ & $1900-10000^{28,31}$ & & $750-1000^{28,31}$ & & $900-1700^{24,31}$ & \\
\hline BMP-9 & $\begin{array}{c}\text { BMPR } \\
\text { immobilized }\end{array}$ & SPR & $<0.008-45^{32,35-37}$ & & & & & $0.6-3.3^{35,36}$ & $6.4-42.7^{35,36}$ & $0.02-1.4^{35,36}$ \\
\hline
\end{tabular}


bioRxiv preprint doi: https://doi. org/10.1101/2020 10.20.348060; this version posted October 21, 2020. The copyright holder for this preprint (which was not certified by peer review) is the author/funder, who has granted bioRxiv a license to display the preprint in perpetuity. It is made available under aCC-BY-NC-ND 4.0 International license.

TABLE 2. Binding affinities ( $K_{D}$ in $\left.n M\right)$ of $B M P / B M P R$ interactions. Tables summarizing the $K_{D}$ $(\mathrm{nM})$ of the BMP/BMPR interactions for: $\mathbf{A})$ type I and $\mathbf{B})$ type II receptors, obtained from the kinetic experiments in a conformation where the BMPR is immobilized. The interactions between BMP9/ALK3 and BMP-9/ALK6 yielded a very low signal (N.A). The high affinity couples are colored in dark blue. The error values represent the s.d $(n=3)$.

A

\begin{tabular}{|c|c|c|c|c|c|}
\hline BMPR & ALK1 & $\begin{array}{c}\text { ALK2 } \\
(\text { ActR-I })\end{array}$ & $\begin{array}{c}\text { ALK3 } \\
(\text { BMPR-IA })\end{array}$ & $\begin{array}{c}\text { ALK5 } \\
(\text { TGFßR-I })\end{array}$ & $\begin{array}{c}\text { ALK6 } \\
(\text { BMPR-IB })\end{array}$ \\
\hline BMP-2 & $13.0 \pm 1.6$ & $7.0 \pm 2.3$ & $0.21 \pm 0.03$ & $5.8 \pm 1.1$ & $0.5 \pm 0.1$ \\
\hline BMP-4 & $55.4 \pm 4.0$ & $10.5 \pm 3.8$ & $1.7 \pm 0.5$ & $21.9 \pm 6.6$ & $3.1 \pm 0.3$ \\
\hline BMP-7 & $23.1 \pm 2.1$ & $18.4 \pm 3.8$ & $19.0 \pm 2.1$ & $22.6 \pm 1.1$ & $15.0 \pm 1.2$ \\
\hline BMP-9 & $0.2 \pm 0.1$ & $133.1 \pm 35.1$ & N.A & $51.0 \pm 18.3$ & N.A \\
\hline
\end{tabular}

B

\begin{tabular}{|l|l|l|l|}
\hline $\begin{array}{r}\text { BMPR } \\
\text { BMP }\end{array}$ & BMPR-II & ACTR-IIA & ACTR-IIB \\
\hline BMP-2 & $5.4 \pm 0.8$ & $6.1 \pm 1.2$ & $6.3 \pm 3.4$ \\
\hline BMP-4 & $56.0 \pm 6.0$ & $21.4 \pm 3.7$ & $26.0 \pm 0.5$ \\
\hline BMP-7 & $5.5 \pm 1.2$ & $1.3 \pm 0.3$ & $7.1 \pm 0.7$ \\
\hline BMP-9 & $0.8 \pm 0.2$ & $1.7 \pm 0.1$ & $1.4 \pm 0.4$ \\
\hline
\end{tabular}


bioRxiv preprint doi: https://doi.org/10.1101/2020 10,20.348060; this version posted October 21, 2020. The copyright holder for this preprint (which was not certified by peer review) is the author/funder, who has granted bioRxiv a license to display the preprint in perpetuity. It is made available under aCC-BY-NC-ND 4.0 International license.

TABLE 3. Binding affinities (K $\left.K_{D}\right)(n M)$ of BMP/BMPR-I/BMPR-II interactions. Table summarizing the $\mathrm{K}_{\mathrm{D}} 1$ and $\mathrm{K}_{\mathrm{D}} 2(\mathrm{nM})$ of the BMP/BMPR-I/BMPR-II interactions obtained from the kinetic experiments in a conformation where ALK2 and type-II BMPR are loaded sequentially. The error values represent the s.d $(n=3)$.

\begin{tabular}{|l|c|c|c|c|c|c|}
\hline & \multicolumn{6}{|c|}{ ALK2 (ActR-I) } \\
\hline $\mathrm{K}_{\mathrm{D}}$ (nM) & \multicolumn{2}{|c|}{ BMPR-II } & \multicolumn{2}{c|}{ ACTR-IIA } & \multicolumn{2}{c|}{ ACTR-IIB } \\
\hline & $\mathrm{K}_{\mathrm{D}}{ }^{1}$ & $\mathrm{~K}_{\mathrm{D}}{ }^{2}$ & $\mathrm{~K}_{\mathrm{D}} 1$ & $\mathrm{~K}_{\mathrm{D}}{ }^{2}$ & $\mathrm{~K}_{\mathrm{D}} 1$ & $\mathrm{~K}_{\mathrm{D}}{ }^{1}$ \\
\hline BMP-2 & $17.8 \pm 7.2$ & $33.0 \pm 10.2$ & $31.7 \pm 6.5$ & $47.8 \pm 4.5$ & $14.4 \pm 2.3$ & $46.1 \pm 11.4$ \\
\hline BMP-4 & $55.8 \pm 17.2$ & $90.7 \pm 33.3$ & $14.1 \pm 2.5$ & $125.0 \pm 20.4$ & $88.7 \pm 22.6$ & $103.2 \pm 39.0$ \\
\hline BMP-7 & $4.6 \pm 0.7$ & $19.1 \pm 6.4$ & $7.1 \pm 1.8$ & $350.6 \pm 12.3$ & $19.1 \pm 5.5$ & $60.7 \pm 22.9$ \\
\hline
\end{tabular}




\section{FIGURES}

A

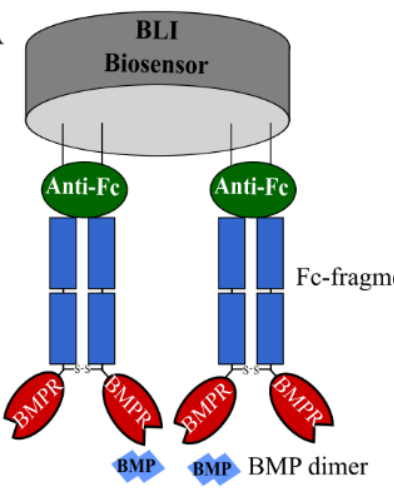

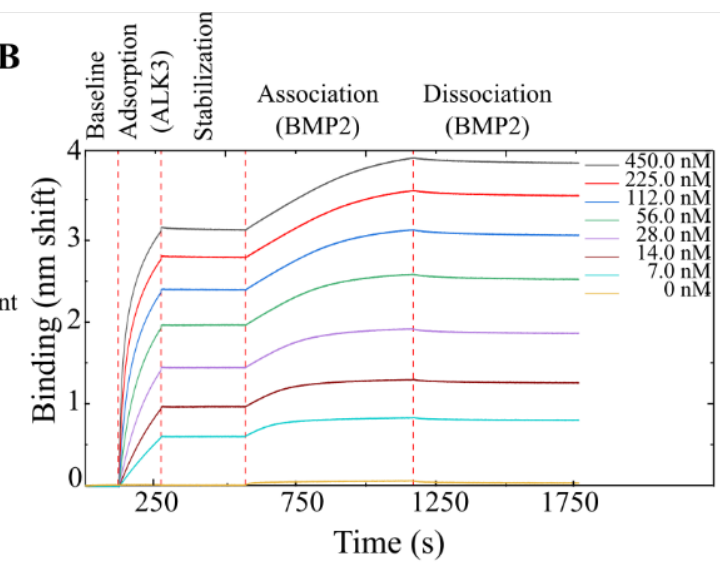

C

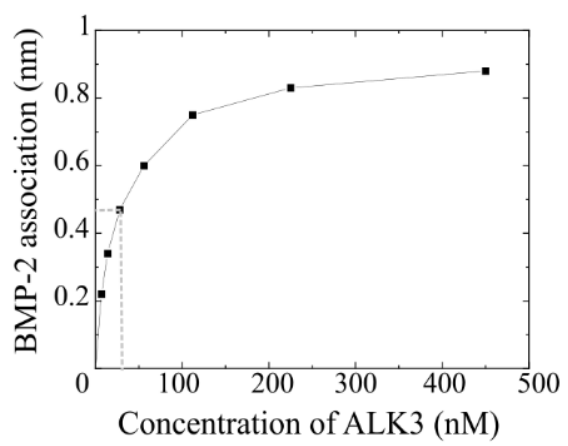

FIGURE 1. Adsorption strategy of BMPR-Fc on the biosensors. A) Schematic representation of the adsorption strategy where an anti-Fc-coated biosensor binds the Fc-Receptor chimera. B) Preliminary experiment where ALK3 receptor was adsorbed at increasing concentrations (from $7 \mathrm{nM}$ to $450 \mathrm{nM}$ ) and set to interact with BMP-2 at a concentration of $5 \mathrm{nM}$. C) The interaction signal of BMP-2 to ALK3 given in nm shift, plotted as a function of ALK3 initial concentration in solution. 

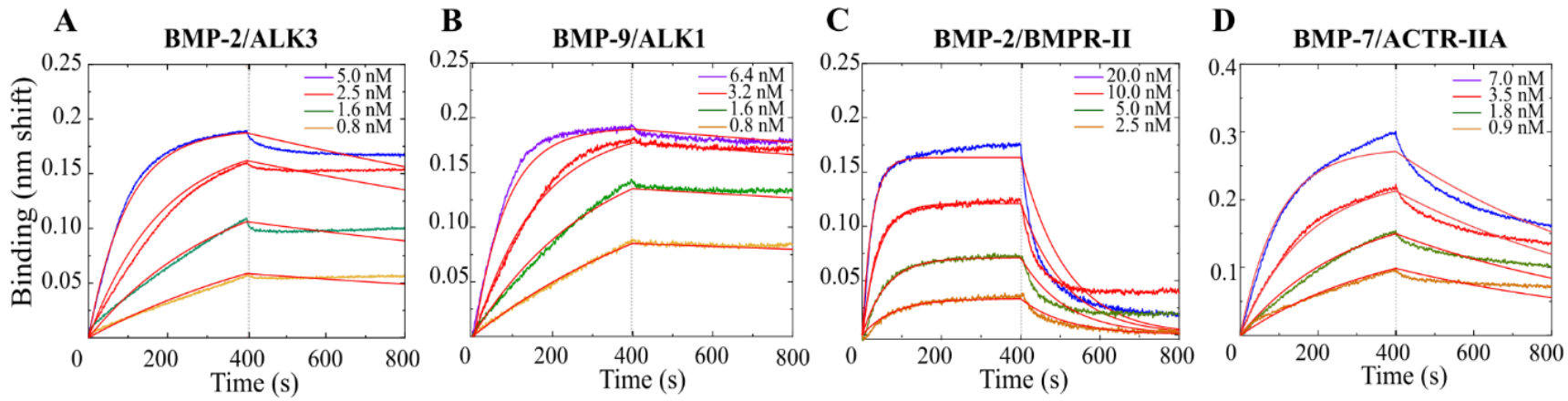

FIGURE 2. Examples of binding kinetics between type-I BMPRs and BMPs. A) BMP-2/ALK3, B) BMP-9/ALK1 and between type-II BMP and BMPs, with C) BMP-2/BMPR-II and D) BMP-7/ACTRIIA. 
A

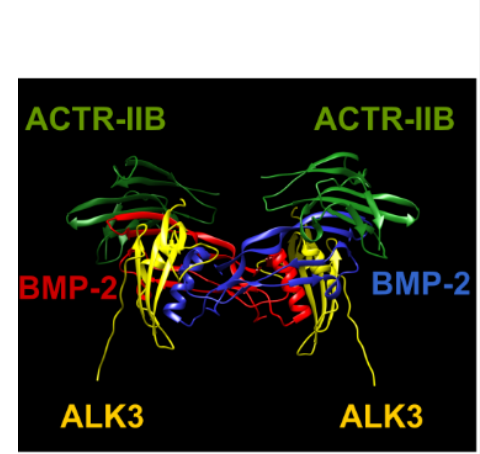

B

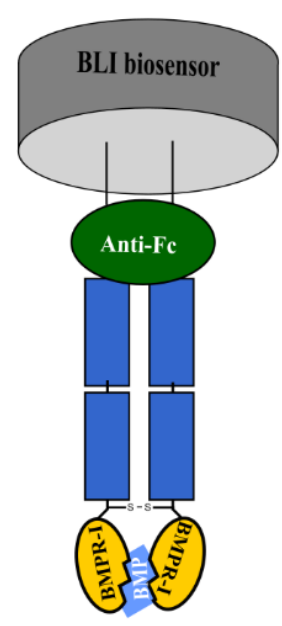

$\mathbf{C}$

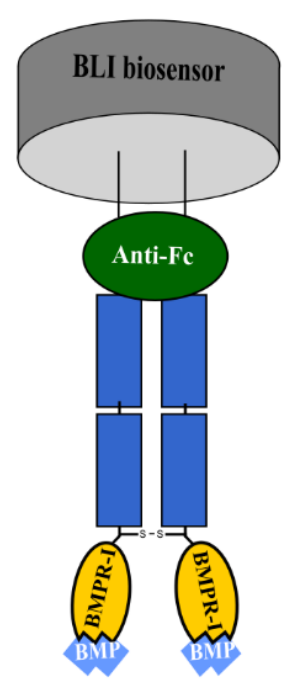

D

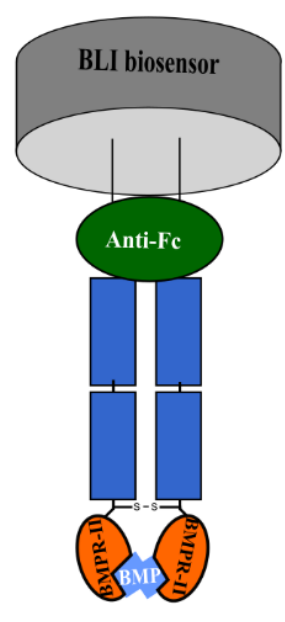

$\mathbf{E}$

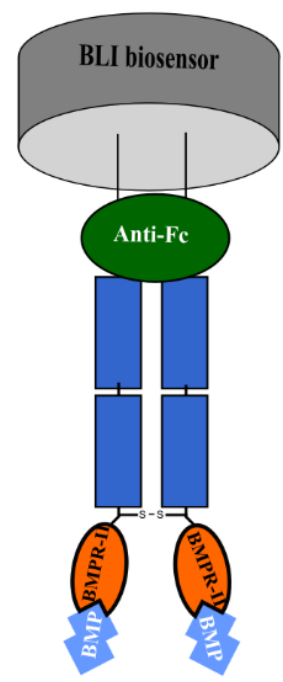

FIGURE 3. A schematic representation of the different binding models in simple BMP/BMPR interaction. A) Picture of BMP-2/ALK3/ACTR-IIB (pdb:2H64) adapted from Weber, D. et al $\boldsymbol{B M C}$ struct Biol 2007 [48]. B) Association of the two binding sites of BMP dimer to two type-I BMPR. C) Association of one binding site of BMP dimer with one type-I BMPR. D) Association of the two binding sites of BMP with two type-II BMPR. E) Association of one binding site of BMP dimer with type-II BMPR. 
A

$k_{\mathrm{a}}$ BMP/BMPR-I

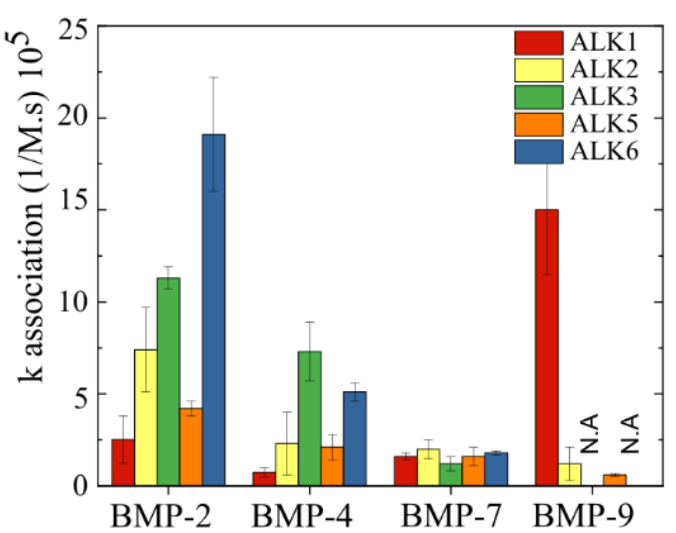

C

$\mathrm{k}_{\mathrm{a}}$ BMP/BMPR-II

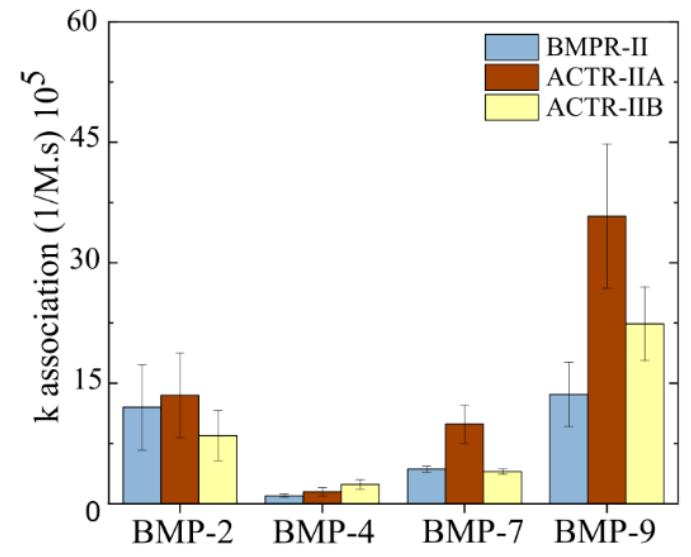

B

$k_{d}$ BMP/BMPR-I

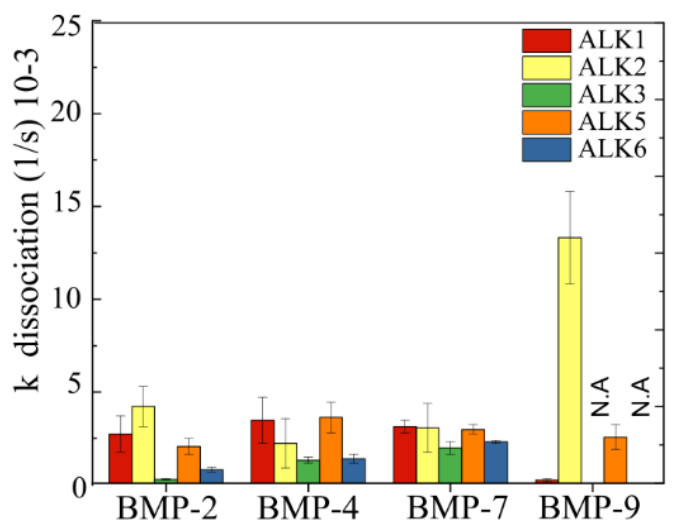

D

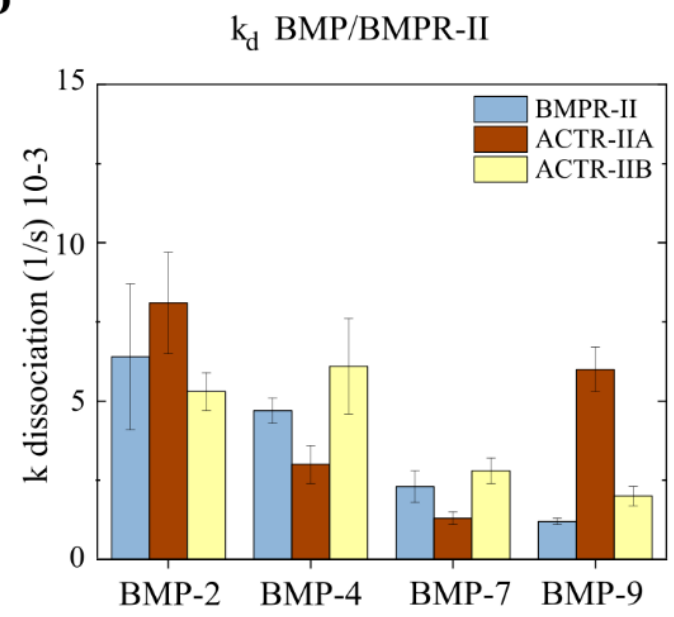

FIGURE 4. Histograms presenting the association constants $\left(k_{a}\right)$ and the dissociation constants ( $\left.\mathbf{k}_{\mathbf{d}}\right) . \mathrm{k}_{\mathrm{a}}$ of A) BMP/type-I BMPR and B) BMP/type-II BMPR interactions and $\mathrm{k}_{\mathrm{d}}$ of $\mathbf{C}$ ) BMP/type-I BMPR and D) BMP/type-II BMPR interactions. For BMP-9/ALK3 AND BMP-9/ALK6, the signal was very low (N.A). The error bars represent the s.d ( $n=3)$. 
A

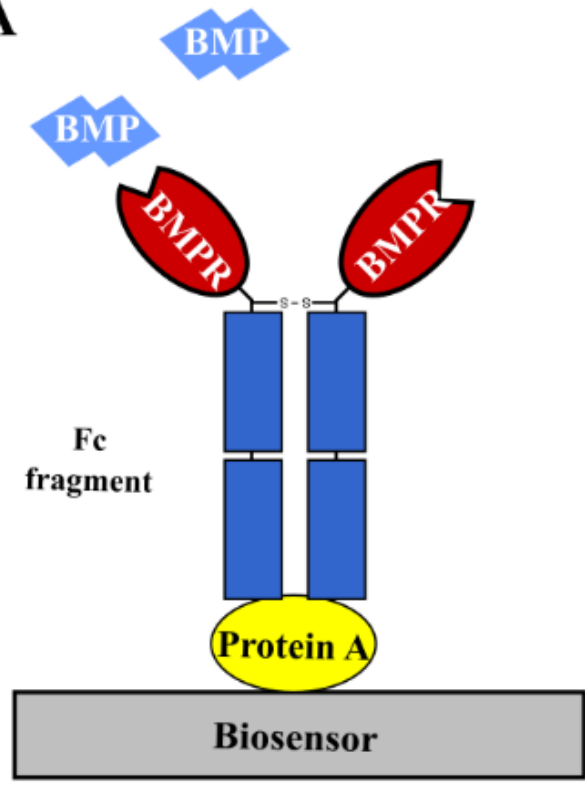

B

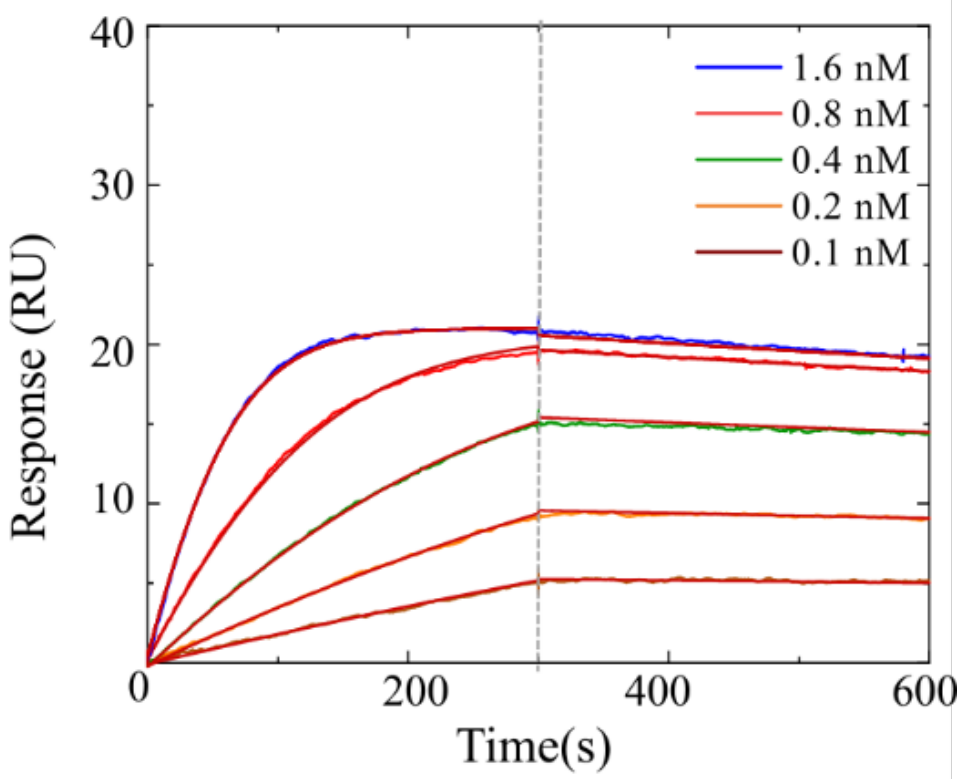

FIGURE 5. SPR study of BMPR/BMP interactions. A) A schematic representation of a SPR biosensor surface where the interaction was studied. Protein A was used to immobilize the BMPR Fc fragment. B) Example of kinetic experiment for the ALK1/BMP-9 couple showing the association phase (up to 300s followed by the dissociation phase). 
bioRxiv preprint doi: https://doi.org/10.1101/2020.10.20.348060; this version posted October 21, 2020. The copyright holder for this preprint (which was not certified by peer review) is the author/funder, who has granted bioRxiv a license to display the preprint in perpetuity. It is made available under aCC-BY-NC-ND 4.0 International license.

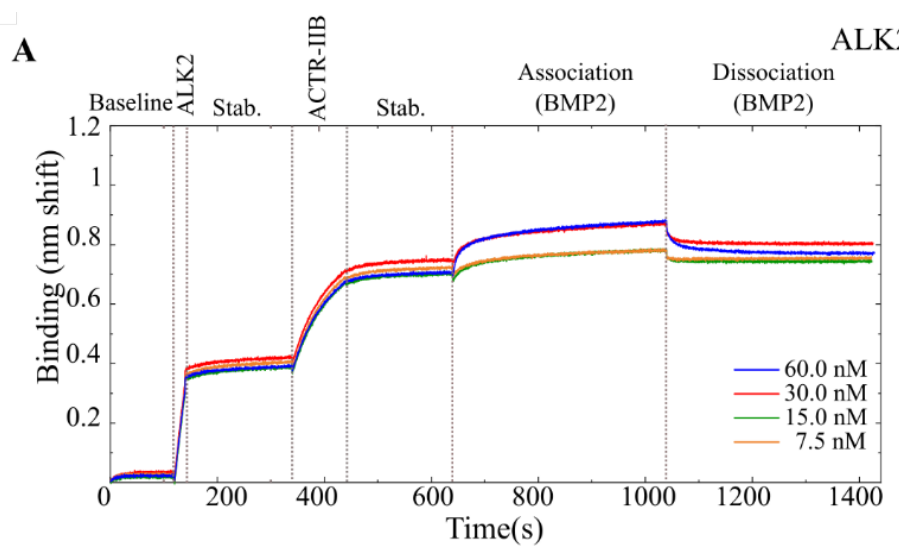

ALK2/ACTR-IIB/BMP-2

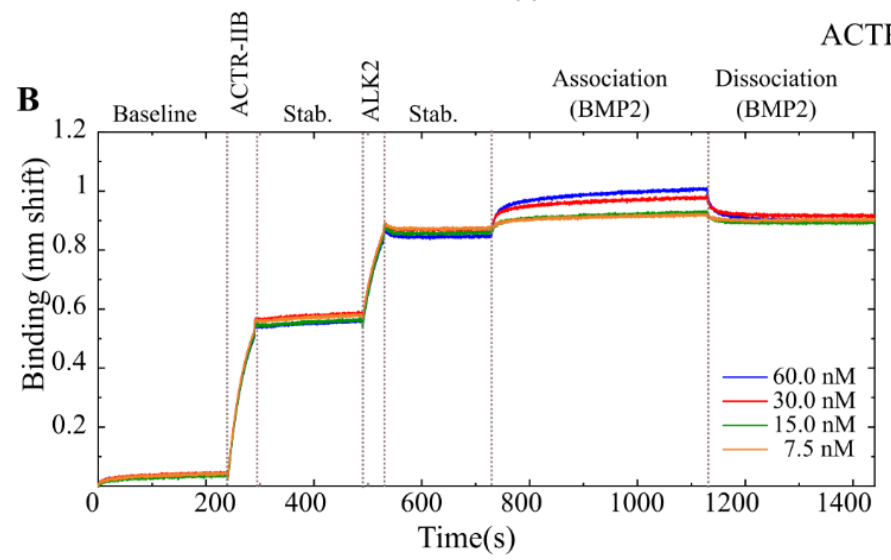

ACTR-IIB/ALK2/BMP-2

C

\begin{tabular}{|c|c|c|c|c|c|c|c|c|}
\hline & \begin{tabular}{|c|}
$\begin{array}{c}\text { Loading } \\
\text { ALK2 } \\
(\mathrm{s})\end{array}$ \\
\end{tabular} & \begin{tabular}{|c|} 
Loading \\
ACTR-IIB \\
(s)
\end{tabular} & \begin{tabular}{|l|l}
$\begin{array}{l}\mathrm{K}_{\mathrm{D}^{1}} \\
(\mathrm{nM})\end{array}$ \\
\end{tabular} & $\begin{array}{c}\mathrm{k}_{\mathrm{a}} 1 \\
\left(\mathrm{M}^{-1} \cdot \mathrm{s}^{-1}\right) \\
10^{5}\end{array}$ & $\begin{array}{c}\mathrm{k}_{\mathrm{d}} 1 \\
\left(\mathrm{~s}^{-1}\right) \\
10^{-3}\end{array}$ & $\begin{array}{l}\mathrm{K}_{\mathrm{D}^{2}} \\
(\mathrm{nM})\end{array}$ & $\begin{array}{c}\mathrm{k}_{\mathrm{a}}{ }^{2} \\
\left(\mathrm{M}^{-1} \mathrm{~s}^{-1}\right) \\
10^{5}\end{array}$ & $\begin{array}{c}\mathrm{k}_{\mathrm{d} 1} \\
\left(\mathrm{~s}^{-1}\right) \\
10^{-3}\end{array}$ \\
\hline Loading order & First & Second & & & & & & \\
\hline ALK2/ACTR-IIB & 20 & 100 & $46.1 \pm 11$. & $12.2 \pm 3.1$ & $56.2 \pm 20.3$ & $14.4 \pm 2.3$ & $1.09 \pm 0.01$ & $1.6 \pm 0.1$ \\
\hline Loading order & Second & First & & & & & & \\
\hline ACTR-IIB/ALK2 & 50 & 40 & $22.9 \pm 1$. & $22.2 \pm 9.9$ & $50.9 \pm 0.3$ & $4.6 \pm 0.2$ & $2.3 \pm 1.1$ & $1.1 \pm 0.5$ \\
\hline
\end{tabular}

FIGURE 6. Interaction between the ALK2/ACTR-IIB heterocomplex and BMP-2. Binding was done sequentially: ALK2 or ACTR-IIB first followed by the second receptor and then BMP-2. A) First ALK2 or B) first ACTR-IIB. C) A representation of a ternary complex model. D) Table summarizing the kinetic parameters deduced from the experimental fit to the data. The stab. step refers to stabilization. 
bioRxiv preprint doi: https://doi.org/10.1101/2020.10.20.348060; this version posted October 21, 2020. The copyright holder for this preprint (which was not certified by peer review) is the author/funder, who has granted bioRxiv a license to display the preprint in perpetuity. It is made available under aCC-BY-NC-ND 4.0 International license. 